\title{
IAMJ
}

INTERNATIONAL

AYURVEDIC

MEDICAL JOURNAL

\section{ROLE OF TRIVIDHA ROGAYATANA IN THE MANIFESTATION OF ESSENTIAL HYPERTENSION W.S.R. TO PRAGYAPARADA - A CONCEPTUAL STUDY}

\author{
Ajay Kumar Nigwal ${ }^{1}$, Lajwanti Keswani ${ }^{2}$, Rajesh Kumar Malviya ${ }^{3}$, Arvind Kumar Yadav ${ }^{4}$ \\ ${ }^{1} \mathrm{PG}$ Scholar, ${ }^{2}$ Associate Professor \& HOD, ${ }^{3}$ Associate Professor \& Guide, ${ }^{4} \mathrm{PG}$ Scholar \\ ${ }^{1,2,3}$ P.G. Dept. of Samhita Siddhant, Pt. Khushilal Sharma Govt. Auto. Ayurved College \& Institute Bhopal \\ (M.P.), India \\ ${ }^{4}$ P.G. Dept. of Rachna Sharir, Pt. Khushilal Sharma Govt. Auto. Ayurved College \& Institute Bhopal (M.P.), India
}

Corresponding Author:ajaynigwal1213@gmail.com

https://doi.org/10.46607/iamj2109082021

(Published Online: August 2021)

Open Access

(C) International Ayurvedic Medical Journal, India 2021

Article Received:05/07//2021 - Peer Reviewed:14/07/2021 - Accepted for Publication:15/07/2021

\section{Check for updates}

\section{ABSTRACT}

Cardiovascular disease such as hypertension will be the largest cause of death and disability in India by 2020 . The prevalence of hypertension is increasing globally and currently, more than 1 billion people have hypertension. About $26.4 \%$ of the world adult population in 2000 had hypertension and $29.2 \%$ were projected to have this condition by 2025. Elevated blood pressure affects 1 billion individuals and causes an estimated 10.4 million deaths per year. Thus, hypertension is needed to be studied. Though a lot of potent antihypertensive drugs are available today none of them is free from untoward adverse effects. Especially the elderly population poorly tolerates these drugs. The global incidence of hypertension is increasing day by day and is a very common problem nowadays. Ayurveda has classified the causes of disease into three main categories: - 1. Asatmendriyartha Samyoga 2. Pragyaparada and 3. Parinama (Kaala), these three main causes of disease enable different kinds of diseases to manifest. Firstly, they lead to the imbalance of body /or mind by vitiation the Tridosha. The consequence of the imbalance is a disturbance of the basic biological principles. Hypertension is a lifestyle disorder. Ayurveda causes of lifestyle disorders are mainly Pragyaparada. Pragyaparadha is the main cause of all noncommunicable diseases (NCDs) such as diabetes, cancer, hypertension etc. 
Keywords: Asatmendriyartha, Pragyaparada, Parinama, Trividha Rogaayatanas, Hypertension.

\section{INTRODUCTION}

The causes of diseases relating to both mind and body are three-fold wrong utilisation, non-utilisation and excessive utilisation of Kala (time), Buddhi (mental faculties) and objects of sense organs ${ }^{1}$ or in another way Asatmyendriyartha Sannikarsha, Prangyaparada and Parinaama. These three causes enable different kinds of diseases to manifest, these are together named as Trividha Rogaayatanas. Among these Pragyaparada stands for knowingly doing wrong things (in general) is the root cause for all miseries. The Pragya in its normal state helps to acquire the proper knowledge thereby leading to normal activities and finally to Swasthya Avastha. One with good knowledge and Pragya will do proper understanding of Hita and Ahita will act accordingly i.e. they will differentiate what is good for their body and mind what is not good for them ${ }^{2}$.Charak in Sharir Sthana opines that the impairment of intellect, patience and memory advent of the maturity of time and action and unwholesome contact with sensory organs are the causative factor for miseries ${ }^{3}$. In the modern era a person whose intellect, patience, and memory are impaired, subjects himself to intellectual blasphemy by virtue of his bad actions ${ }^{4}$. Pragyapara$d a$ (intellectual blasphemy) leads to vitiation of tri Doshas, and it has a major role in disease manifestation $^{5}$. Hypertension is a most common lifestyle disorder and is a very strong risk factor for CVDs. It is a chronic condition in which blood pressure in the artery is elevated ${ }^{6}$. Hypertension is defined as systolic blood pressure greater than or equal to $140 \mathrm{mmHg}$ or diastolic pressure greater than or equal to $90 \mathrm{~mm} \mathrm{Hg}$ or currently taking medication to lower high blood pressure $^{7}$. It is also called the silent killer because in this the patient remains mostly asymptomatic but, in some cases, it is reported with headache vertigo, light headiness etc ${ }^{8}$. The exact cause of hypertension is not known but it is greatly influenced by diet and lifestyle-related modifiable risk factors like alcohol con- sumption, excess intake of salt, physical inactivity etc. $^{9}$

\section{AIM AND OBJECTIVES:}

- To study Trividha Rogaayatanas.

- To rule out Pragyaparada as a causative factor for systemic Hypertension.

\section{- MATERIAL AND METHODS} STUDY DESIGN

- The study will be designed as an observational study and the sample will be collected by simple random sampling technique.

- Questionnaire method.

- The questionnaire contains demographic details Name, age, gender, occupation, marital status and Pragyaparada and HTN related questions.

TRIVIDHA ROGAYATANA: Ayurveda is an ancient science. There are many Siddhanta described in Ayurveda. Now a day's many studies are conducting on these Siddhanta. The main aim of Ayurveda is to maintain the healthy state of the individual and to treat the disease. In Charak Samhita, Acharya Charak mentioned a wise person should be vigilant about his duties towards his own body like an officer-in-charge of a city and a charioteer towards the city and the chariot respectively ${ }^{10}$. According to Acharya Charak, there are three primary causes of manifestation of diseases i.e. Asatmyendriyasanyoga, Pragyaparadha and Parinama. In these Pragyaparadha is the main reason for disease ${ }^{11}$.

PRAGYAPARADHA: Pragyaparadha made up of two words, Pragya and Aparadha. Word Pragya denotes wisdom and aparadha denote action against rules, hence inappropriate work done by a person is known as Pragyaparadha. Dhi, Dhriti, Smriti are three factors which affect Pragya, and these are known as a pillar of it ${ }^{12}$. When the Dhi, Dhriti, Smri$t i$, do not carry out their respective function properly due to their derangement it causes the occurrence of Ashubha karma. These Ashubha karma cause vitiation of all Doshas, and imbalance of Doshas is one of 
the major causes of illness. In Charak Samhita, pravritti of vachan, mana, and shareer is known as karma and Ayoga, Atiyoga and Mithyayoga of these karmas known as Pragyaparada ${ }^{13}$ Ignorance of rules of Prakriti also is called Pragyaparadha.

Lifestyle disorders: The way a person lives is called 'lifestyle'. The modern health system recognizes some disorders related to flawed lifestyle. These disorders are called lifestyle disorders (LD) or noncommunicable diseases (NCD). They are also called the diseases of civilization. Some of the common lifestyle disorders are as follows ${ }^{14}$ : Hypertension, Allergy, Heart diseases, Anxiety, Depression, Hyperlipidemia, Cancer, Insomnia Constipation, Irritable bowel syndrome, Obesity etc.

The causes of lifestyle disorders can be divided into two main categories:

1. Modifiable behavioural risk factors,

2. Non-modifiable risk factors and

\section{Modifiable behavioral risk factors:}

1. Wrong food habits: Eating when not hungry, overeating, eating at odd hours, eating unhealthy food and skipping food. Excessive use of sodium in the diet causes 4.1 million deaths per year as per the WHO report ${ }^{15}$.

2. Addiction: Alcoholism, smoking and tobacco. According to the WHO, the mortality rate due to the use of tobacco is more than 7 million per year and alcohol consumption leads to around 1.65 million deaths ${ }^{16}$.

3. Wrong physical activity: Sitting for long hours, wrong body posture and remaining indoors. The modern occupational settings (desk jobs) and the stress related to work is a strong risk factor for LDs. A simple lack of physical activity has been claiming1.6 million lives annually ${ }^{17}$.

4. Disturbed biological clock: Sleeping late, waking up late, not sleeping, and oversleeping. A disturbed biological clock increases the likelihood of LDs.

\section{Non-modifiable risk factors:}

Risk factors that cannot be controlled or modified by intervention are called non-modifiable risk factors. These are age, race, gender, and genetics.
CRITERIA FOR ASSESSMENT: Demographic data and data related to the Pragyaparada and HTN will be accessed based on a specially designed questionnaire including signs and symptoms mentioned below.

\section{OBJECTIVE CRITERIA:}

1. BMI

\section{BLOOD PRESSURE}

\section{DATA MANAGEMENT AND STATISTICAL} ANALYSIS:

Data collected by questionnaire and will be coded and entered Number Software, excel software etc. Data were analysed using suitable statistical techniques like ratio, averages, percentage etc. and with the help of a suitable test, a statistical package for social science (SPSS) will use for analyses.

\section{DISCUSSION}

Pragyaparada is lead to many diseases. Wrongful actions have erupted from wrongful thinking. Wrongful thinking erupts from the mind that is not pure and clear. When the mind is adulterated by Rajas and Tamas Guna it cannot learn clearly, think clearly, and decide clearly. Psychologists opine that man tends to be attracted towards the 'wrong'. Wishing to do what one is not supposed to do is called 'Temptation'. This is nothing but 'Pragyaparadh'. When the Satva quality of intellect recedes and Rajas and Tamas qualities augment, the intellect becomes deranged and tends to make wrong interpretations of knowledge. Favourable time, sense objects which are agreeable to the mind, virtuous activities which bestow happiness, control of mind and clear intellect, all these are ideal for promotion of health and accomplishment of happiness. Hypertension is the cause of Tridoshas Vyadi and also the involvement of Manshik Gunas like Raja \&Tama. The imbalance of Doshas leads to diseases like hypertension. The cause of imbalance according to Ayurveda is Trividh Rogaayatana mainly Pragyaparada e.g. changes in unhealthy diet and daily routine. Present world facing these conditions nowadays and increases the prevalence of diseases due to Pragyaparada. 


\section{CONCLUSION}

According to Ayurveda disease manifests begins with the formation of Ama in the body. It has a tremendous capacity to vitiate the Doshas and disturbing homeostasis (Dhatu-Samya). Causes of Ama production is irregular diet and lifestyle caused by Pragyaparada. Imbalances of Doshsa, Dhatus \&Mala are diseases stage and it caused by Trividhrogayatan specially Pragyaparada. In the present scenario, human beings have a lack of time and stress full life, which leads to lifestyle disorders. If we understand the relation between lifestyle disorders and Trividhrogayatan (specially Pragyaparada) and aware to people about these causes according to Ayurved science. We can succeed in the prevention of lifestyle disorders like hypertension. So, we can say Pragyaparada play important role in the manifestation of hypertension.

\section{REFERENCES}

1. Dr. Ram Karan Sharma Vaidya Bhagavan Dash Editor, Charakasamhita by Agnivesha. Reprinted. Varanasi: Chaukamba Sanskrit Series 2013.Vol 1.Verse54.P.39.

2. Dr. Ram Karan Sharma Vaidya Bhagavan Dash Editor, Charakasamhita by Agnivesha. Reprinted. Varanasi: Chaukamba Sanskrit Series 2013.Vol 11. Verse99. P.336.

3. Dr. Ram Karan Sharma Vaidya Bhagavan Dash Editor, Charakasamhita by Agnivesha. Reprinted. Varanasi: Chaukamba Sanskrit Series 2013.Vol 11. Verse 98.P.336.

4. Dr. Ram Karan Sharma Vaidya Bhagavan Dash Editor, Charakasamhita by Agnivesha. Reprinted. Varanasi: Chaukamba Sanskrit Series 2013.Vol 11. Verse 102.P.337.

5. Dr.Ram Karan Sharma Vaidya Bhagavan Dash Editor, Charakasamhita By Agnivesha. Reprinted. Varanasi: Chaukamba Sanskrit Series 2013.Vol 11. Verse 102.P.337.

6. Y P Munjal. API Textbook Of Medicine. Reprint Edition New Delhi: Jaypee Brothers Medical Publishers 2015.Vol 1. Page917.

7. Y P Munjal. API Textbook Of Medicine. Reprint Edition New Delhi: Jaypee Brothers Medical Publishers 2015. Vol 1.Page16.

8. Https://Www.Who.Int.News-Room/Facts Sheets/Details/Hypertension

9. Https://Www.Who.Int.News-Room/Facts Sheets/Details/Hypertension
10. Shastri Pt. Kashinath And Dr Gorakhanath Chaturvedi, Ed. Charak Samhita Of Agnivesh, Sutrasthan. Reprint Ed, Ch.5, Ver.103 Vol.1. Varanasi; Chaukhambha Bharati Academy Publication; 2014: P.132

11. Shastri Pt. Kashinath And Dr Gorakhanath Chaturvedi, Ed. Charaka Samhita Of Agnivesh, Sutrasthan. Reprint Ed, Ch.11, Ver.43 Vol.1. Varanasi; Chaukhambha Bharati Academy Publication; 2017: P.233

12. Dr. B. K. Dwivedi and Dr. Lakshmidhar Dwivedi, Ed. Ayurvediyabhootviddha vivechan, Vishishtmanovyapar. Reprint Ed, Ch.06, Varanasi; Krishnadas Academy Publication;1997: P.125

13. Shastri Pt. Kashinath And Dr Gorakhanath Chaturvedi, Ed. Charaka Samhita Of Agnivesh, Sutrasthan. Reprint Ed, Ch.11, Ver.43 Vol.1. Varanasi; Chaukhambha Bharati Academy Publication; 2017: P.233

14. S.A.Tabish. Lifestyle Diseases: Consequences, Characteristics, Causes and Control. Medcrave. Journal Of Cardiology and Current Research Vol 9 Issue 3-2017 Eissn-JCCR

15. Sharma M, Majumdar PK (2009). Occupational Lifestyle Diseases: An Emerging Issue. Indian Journal Of Occupational And Environmental Medicine, 2009 Dec.13 (3), 109-112.

16. WHO (2017). Noncommunicable Diseases. Fact Sheet. (Retrieved From: Http://Www.Who.Int/Mediacentre/Factsheets/Fs355/E n/ On 2/05/2017) Ibid

17. WHO (2011). Global Status Report On Noncommunicable Diseases 2010. (Retrieved FromHttp://Www.Who.Int/Nmh/Publications/Ncd.Re port Full.En.Pdf On 1/05/2017)

\section{Source of Support: Nil Conflict of Interest: None Declared}

How to cite this URL: Ajay Kumar Nigwal et al: Role of Trividha Rogayatana In The Manifestation Of Essential Hypertension W.S.R. To Pragyaparada - A Conceptual Study. International Ayurvedic Medical Journal \{online\} 2021 \{cited August 2021\} Available from: http://www.iamj.in/posts/images/upload/1733_1736.pdf 